\title{
TGFB2 wt Allele
}

National Cancer Institute

\section{Source}

National Cancer Institute. TGFB2 wt Allele. NCI Thesaurus. Code C52016.

Human TGFB2 wild-type allele is located within $1 \mathrm{q} 41$ and is approximately $95 \mathrm{~kb}$ in length.

This allele, which encodes transforming growth factor beta- 2 protein, plays a role in cellular growth and embryogenesis. 